\title{
Microstructures and Mechanical Properties of Al-Zn-Sn Bearing Alloys for High Performance Applications
}

\author{
Nermin Ali Abdelhakim*, Rizk Mostafa Shalaby \\ Metal Physics Laboratory Researsh, Department of Physics, Faculty of Science, Mansoura University, Mansoura, Egypt \\ Email: ${ }^{\star d r n e r m i n a l i @ m a n s . e d u . e g ~}$
}

How to cite this paper: Abdelhakim, N.A. and Shalaby, R.M. (2021) Microstructures and Mechanical Properties of Al-Zn-Sn Bearing Alloys for High Performance Applications. World Journal of Engineering and Technology, 9, 637-652.

https://doi.org/10.4236/wjet.2021.93045

Received: July 9, 2021

Accepted: August 14, 2021

Published: August 17, 2021

Copyright ( 2021 by author(s) and Scientific Research Publishing Inc. This work is licensed under the Creative Commons Attribution International License (CC BY 4.0).

http://creativecommons.org/licenses/by/4.0/

\begin{abstract}
The mechanical behavior and indentation creep of Al-20 wt\% $\mathrm{Zn}$ bearing alloy has been modified with adding $0.2 \mathrm{wt} \%, 0.5 \mathrm{wt} \%, 1 \mathrm{wt} \%, 1.5 \mathrm{wt} \% \mathrm{Sn}$. These bearing alloys were prepared by melt spinning technique. The scanning electron microscopy (SEM) was used to study the morphology of the melt spun alloys and $\mathrm{x}$-ray diffractometer (XRD) for the identification of the phases present in these melt-spun bearing alloys. The results show that the structure of $\mathrm{Al}_{80-\mathrm{x}}-\mathrm{Zn}_{20}-\mathrm{Sn}_{\mathrm{X}}(\mathrm{X}=0.2 \%, 0.5 \%, 1 \%$ and $1.5 \%)$ bearing alloys is characterized by the presence of $\alpha-\mathrm{Al}$ of FCC structure and SnZn intermetallic compound of anorthic structure. The Al-20Zn-1.5Sn has a smaller crystallite size and grain size as indicated from X-ray and SEM analysis respectively, which leading to the enhancement of the mechanical properties. The mechanical properties and indentation creep of these bearing alloys were studied by tensile test machine and vickers indentation testing at room temperature, respectively. The Al-20Zn$1.5 \mathrm{Sn}$ has higher hardness value and creep resistance than other alloys. This was attributed to the strengthen effect of Sn as a strong solid solution element in Al-matrix. The stress exponent values in the range $2.4-4.2$ indicate that the grain boundary sliding is the possible mechanism during room temperature creep deformation of melt-spun Al-Zn-Sn bearing alloys.
\end{abstract}

\section{Keywords}

Bearing Alloys, Microstructure, Mechanical Properties, Microhardness, Indentation Creep

\section{Introduction}

Aluminum-based alloys have superior properties such as corrosion resistance, high thermal conductivity, high fatigue strength, building material for metallic 
structure, lightweight, low price, and operability that are higher than conventional materials and can be used at some high temperature [1]. But besides the above advantages, the engineering applications of some aluminum alloys are constrained by their weak strength and quite soft. However, the strength and hardness are developed by adding alloying elements [2]. The aluminum matrix of alloy bearing motor can be enhanced by the addition of copper, nickel, chromium, manganese, tin and zinc. So that adding tin to aluminum alloys attains an acceptable balance of strength and soft surface properties. Tin as an alloy element with aluminum alloys has the objective of reducing friction in loading and lining applications, because the tin phase in these alloys melted at lower temperature $\left(227.7^{\circ} \mathrm{C}\right)$ and can be exhaled in emergency conditions to provide short-term liquid lubrication to rubbing surfaces if such bearings/bushings severely overheat in service [3]. The presence of zinc in aluminum has a great effect, where the difference in the atomic radius of these two elements $(0.143 \mathrm{~nm}$ for $\mathrm{Al}$ and $0.134 \mathrm{~nm}$ for $\mathrm{Zn})$ has also a very significant influence on the microstructure of the Al-Zn alloys [4]. Since the radius of $\mathrm{Zn}$ is roughly equal to that of $\mathrm{Al}, \mathrm{Zn}$ has high solubility in $\mathrm{Al}$ matrix. The lattice distortion is low by adding $\mathrm{Zn}$, which almost has no effect on formability of the alloy [5].

During recent decades, non-equilibrium processes, such as rapid solidification and ball-milling, have been developed to produce refined controllable microstructures in immiscible systems. The main attributions of rapid solidification are the extension of solid solution, refinement of structures in the nanometer range, production of a fine dispersion of the second phase, synthesis of novel crystalline, and amorphous phases [6] [7] [8] [9]. At the transition from liquid state to solid state in rapid solidification processing (RSP) occurs rapid extraction of thermal energy, this leads to produce manufactured material of extraordinary and has unique properties, i.e., reduced levels of segregation, increasing the solid solubility of alloying components, decrease in the grain size, and in some states the figuration of metastable crystalline and amorphous phases. By means of a rapid solidification technique, Al-based (Al-In [10], Pb [11], Sn [12], Cd [13]) alloys have been synthesized with uniform distributions of the fine immiscible particles embedded in the matrix, indicating that the microstructure could be considerably refined with superior microstructure, mechanical and thermal properties compared to their conventionally processed materials.

It is well recognized [14] [15] [16] [17] [18] that the metallurgical parameters affect considerably the resulting mechanical strengths of distinctive Al-based alloys produced using different manufacturing routes. For instance, an as-casting alloy sample due to its microstructural array has their resulting properties significantly affected. For this reason, in this investigation the metallurgical aspects (microstructural array) of the examined alloy samples are parameterized in all experimentations.

Thus, in the present study, the effects of tin additions on the structure, mechan$\mathrm{ical}$, creep properties and thermal behavior of $\mathrm{Al}_{80-\mathrm{x}}-\mathrm{Zn}_{20}-\mathrm{Sn}_{\mathrm{X}}(\mathrm{X}=0,0.2 \%, 0.5 \%$, 
$1 \%$ and $1.5 \%)$ rapidly solidified alloys from melt were investigated.

\section{Experimental Techniques}

\subsection{Preparation of Samples}

Five bearing $\mathrm{Al}_{80-\mathrm{x}}-\mathrm{Zn}_{20}-\mathrm{Sn}_{\mathrm{X}}(\mathrm{X}=0,0.2 \%, 0.5 \%, 1 \%$ and $1.5 \%)$ alloys were prepared from purely aluminum, zinc and tin (purity $>99.99 \%$ ) Table 1 . These alloys were put in a porcelain crucible and melted by an electric furnace at $700^{\circ} \mathrm{C}$. After $25 \mathrm{~min}$ from heating, the alloys became in a molten. The molten alloys are shooting on the rotating copper wheel which has a linear speed of $31.4 \mathrm{~m} / \mathrm{s}$ giving a cooling rate of $\sim 3.7 \times 10^{5} \mathrm{~K} / \mathrm{s}$ [19]. Increasing cooling rate was reported to increase solid solubility and hence decrease the micro segregation and therefore the second phase content [20] [21]. More alloying elements will remain in the primary $\alpha$ - $\mathrm{Al}$ dendrites that strengthen them by solid solution hardening. Increasing cooling rate also decreases the scale of microstructure, which in turn increases the strength of the alloy. Both these effects are beneficial because the application of the current alloy in bearing applications needs to be stronger.

\subsection{Characterization of Alloys}

Various techniques were used to investigate the structural properties of rapidly solidified alloys including $\mathrm{x}$-ray diffraction using $\mathrm{Cu} \mathrm{K} \alpha$ radiation at room temperature. The thermal properties of $\mathrm{Al}_{80-\mathrm{x}}-\mathrm{Zn}_{20}-\mathrm{Sn}_{\mathrm{X}}(\mathrm{X}=0,0.2 \%, 0.5 \%, 1 \%$ and $1.5 \%$ ) bearing alloys studied by differential scanning calorimetry is carried out by [(DSC-16, Setaram, France) with a heating rate $10 \mathrm{~K} / \mathrm{min}$ [22]. Scanning electron microscopy (SEM) of type (JEOL JSM-6510LV, Japan) operate at $30 \mathrm{KV}$ with high resolution $3 \mathrm{~nm}$ has been used to study the microstructure analysis.

\subsection{Measurements of Mechanical Properties}

\subsubsection{Tensile Test Machine}

Tensile test machine [23] at tensile scan rate of $10 \mathrm{~mm} / \mathrm{sec}$ was installed in our metal physics lab and its schematic diagram is shown in Figure 1. This technique is one of the most commonly accepted techniques in estimation of the mechanical features of metals. Its basic objective would be to determine the properties relevant to the elastic design of materials and structures. In tensile testing,

Table 1. Composition of aluminium bearing alloys.

\begin{tabular}{ccccc}
\hline \multirow{2}{*}{ alloy } & \multicolumn{3}{c}{ Element content (wt\%) } & $\begin{array}{c}\text { Density } \\
\left(\mathrm{g} / \mathrm{cm}^{3}\right)\end{array}$ \\
\cline { 2 - 4 } & $\mathrm{Al}$ & $\mathrm{Zn}$ & $\mathrm{Sn}$ & 2.702 \\
Al-Zn & 80 & 20 & 0.0 & 2.705 \\
Al-Zn-Sn & 79.8 & 20 & 0.2 & 2.710 \\
Al-Zn-Sn & 79.5 & 20 & 0.5 & 2.719 \\
Al-Zn-Sn & 79 & 20 & 1 & 2.727 \\
Al-Zn-Sn & 78.5 & 20 & 1.5 & \\
\hline
\end{tabular}




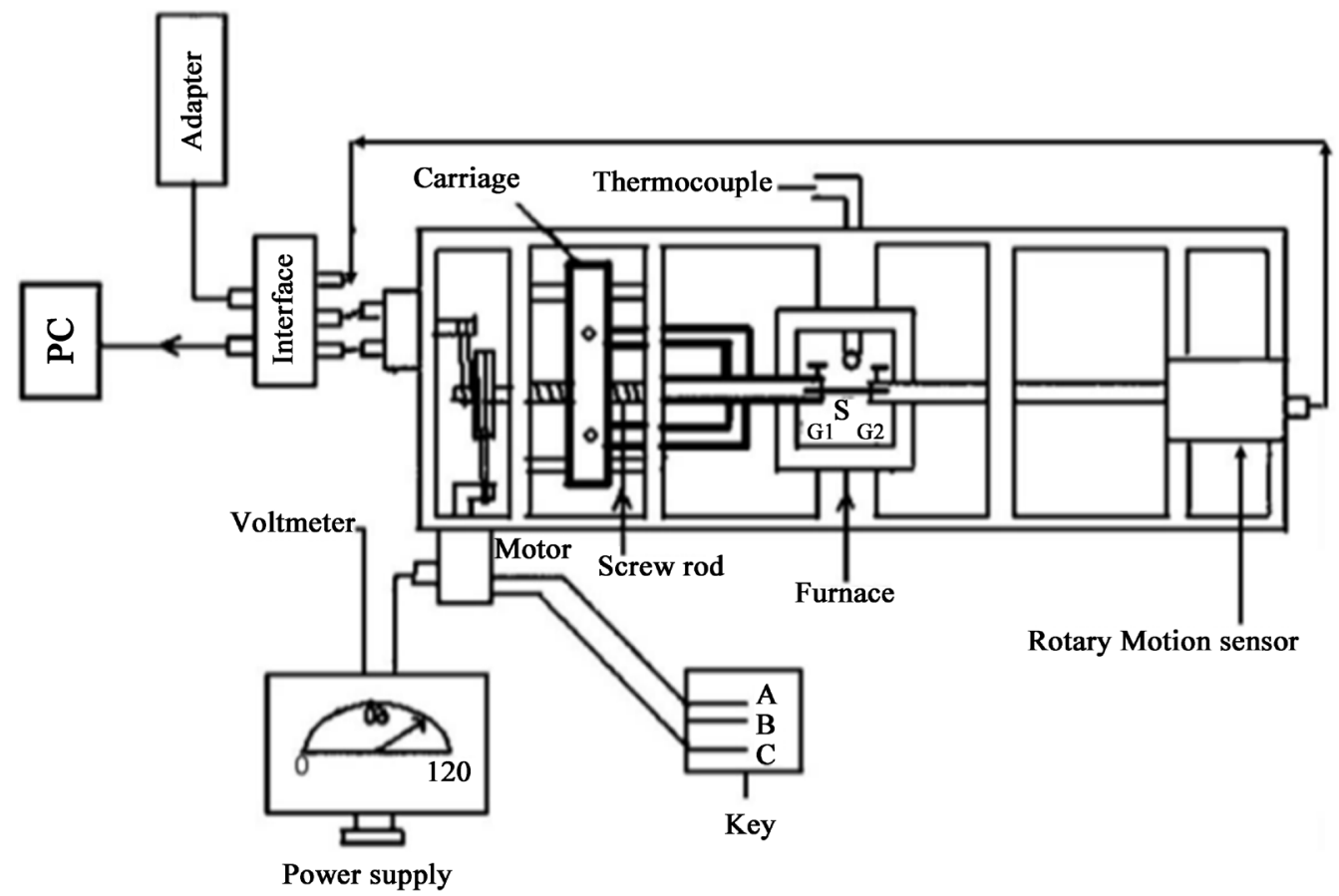

Figure 1. The schematic diagram of tensile test machine.

sample to be tested is machined to standard dimensions (generally $40 \mathrm{~mm}$ length, $0.153 \mathrm{~mm}$ thickness and $2 \mathrm{~mm}$ width) with cross sectional area nearly equals 0.306 $\mathrm{mm}$. Five samples per alloys were tested. Expected elastic and plastic deformations will happened after applied external loads on a specimen. Initially, an elastic deformation will occur to the metal resulting in a linear relationship of load and extension. The applied load (stress) and the resulting strain (elongation) are measured computerized. Using this data, a stress-strain diagram is drawn using computer setting that contains software program to detect the tensile properties.

\subsubsection{Vickers Micro Hardness and Micro Indentation Creep}

Micro hardness test for $\mathrm{Al}_{80-\mathrm{x}}-\mathrm{Zn}_{20}-\mathrm{Sn}_{\mathrm{X}}(\mathrm{X}=0,0.2 \%, 0.5 \%, 1 \%$ and $1.5 \%)$ alloys were performed by using a digital Vickers micro hardness tester (Model FM-7 Future-Tech. Corp. Tokyo Japan). Vickers hardness test is one of the standard methods that measure the hardness of metals, especially those having extremely hard surfaces. Among the great advantages of the micro indentation creep techniques are: quick, easy, accuracy and non-destructive method. In addition, only one type of indenter can be used for all types of metals and surface treatments [24] [25]. Although they are highly adaptable and more accurate for testing the most soft and hard materials under different loads, the surface is subjected to standard pressure for a standard interval of time by means of a pyramid-shaped diamond. The indenter is a square pyramid that meets its opposite sides at the top with an angle of 136 degrees. It makes the diamond pressure in the material surface in loads $10 \mathrm{gf}$, and the impression size (usually no greater than $0.5 \mathrm{~mm}$ ) is measured by the microscope. The impression left by the Vickers indenter is a square dark on a light background. Microscope swings on a sample to measure 
the square indentation to tolerance of $\pm 1 / 1000$ of millimeters. Average measurements (ten measurements for each alloy) taken across diameters are calculated to determine the region.

The number of Vickers (HV) is calculated by using the following formula [24] [25]:

$$
\mathrm{HV}=\frac{2 F \sin \frac{136^{\circ}}{2}}{d^{2}}
$$

So that $\mathrm{HV}=\frac{1.854 F}{d^{2}}$ approximately, where $F$ is the applied load force, $d$ is the average diagonal length.

\section{Results and Discussion}

\subsection{Structure Analysis}

Figure 2 shows the XRD patterns for the melt-spun $\mathrm{Al}_{80-\mathrm{x}}-\mathrm{Zn}_{20}-\mathrm{Sn}_{\mathrm{X}}(\mathrm{X}=0,0.2 \%$,
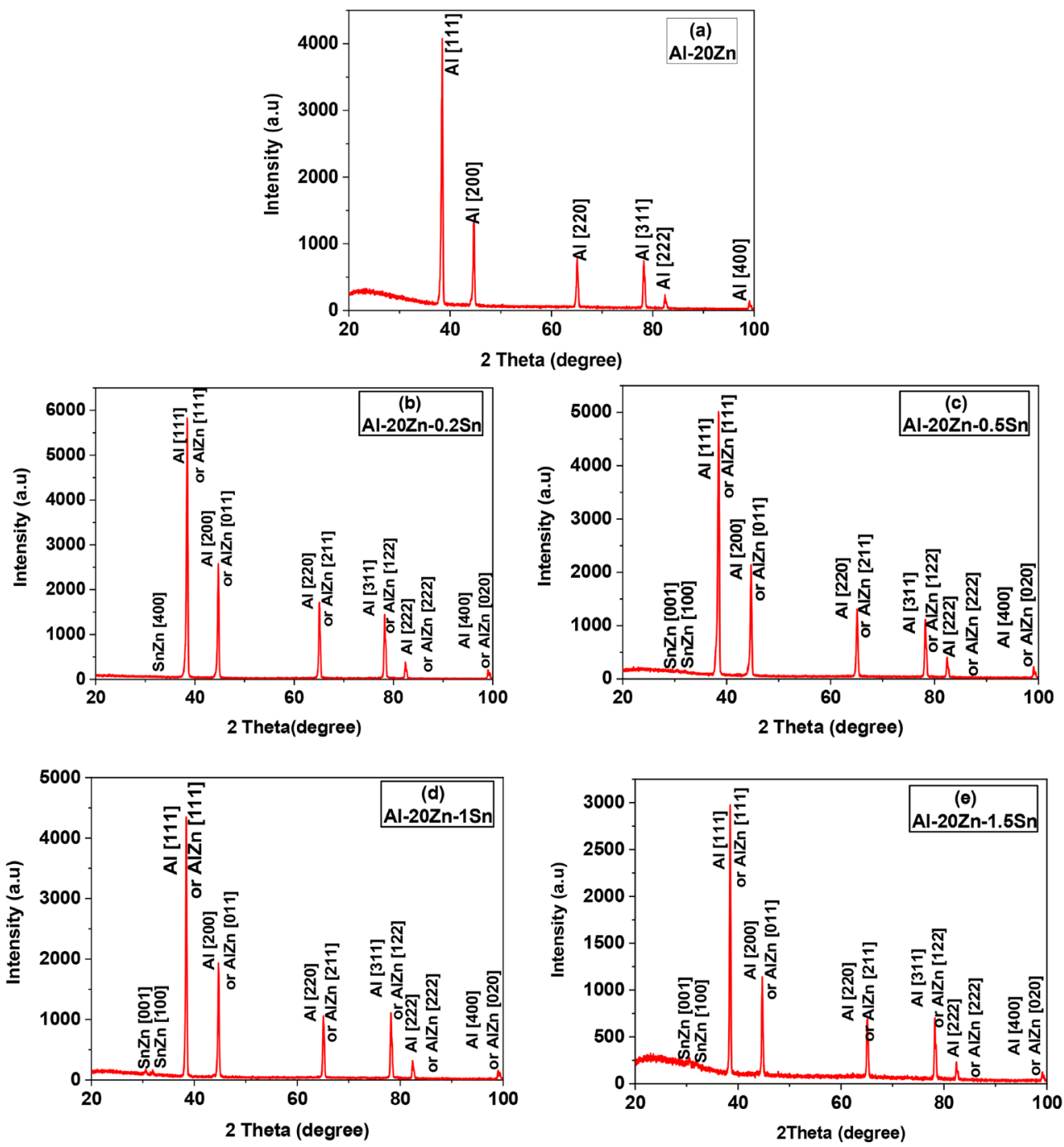

Figure 2. The XRD patterns of aluminium bearing alloys. 
$0.5 \%, 1 \%$ and $1.5 \%$ ) bearing alloys. The XRD pattern for all Al-20Zn-Sn alloys show that two phases $\alpha$-Al of face centered cubic structure and AlZn intermetallic compound of anorthic structure exist together at the same $2 \theta$ values. By addition of tin, tin combines with zinc forming SnZn phase of hexagonal structural. The XRD analysis is listed in Table 2. The crystal size (D) was calculated from the XRD pattern by using Scherer formula [26].

$$
D=\frac{0.9 \lambda}{\beta \cos \theta}
$$

where $\theta$ is the Bragg angle, $\lambda$ is the $\mathrm{x}$-ray wavelength; $\beta$ is the broadening of the diffraction line measured at half its maximum intensity (FWHM). The crystal size of $\mathrm{Al}$ phase is decreased by increasing $\mathrm{Sn}$ content in the $\mathrm{Al}$ matrix which enhances the mechanical properties of $\mathrm{Al}$ bearing alloys.

After calculating volume of the unit cell $(V)$ by through the lattice parameters, the number of atoms in the unit cell $(n)$ is calculated using the following equations [27].

$$
\begin{gathered}
\Sigma A=\frac{p v}{1.66020} \\
\Sigma A=n A w
\end{gathered}
$$

where $\Sigma A$ is the sum of the atomic weights of the atoms in the unit cell, $\rho$ is the density $\left(\mathrm{gm} / \mathrm{cm}^{3}\right)$ listed in Table 1 and $v$ is the volume of the unit cell $\left(\mathrm{nm}^{3}\right)$, and Aw is the molecular mass. The number of the atoms per unit cell was calculated which is non-integral number of atoms per cell. Therefore, some of the atoms may be absent from some fraction of those lattice sites, which they would

\begin{tabular}{|c|c|c|c|c|c|c|}
\hline Melt-spun ribbons & $\begin{array}{l}\text { JCPDS } \\
\text { number }\end{array}$ & $\begin{array}{c}\text { Phase } \\
\text { designation }\end{array}$ & $\begin{array}{l}\text { No of } \\
\text { phases }\end{array}$ & Crystal system & $\begin{array}{c}\text { Crystallite size D } \\
(\mathrm{nm})\end{array}$ & $\begin{array}{c}\text { No of atoms/unit cell } \\
\text { of } \mathrm{Al} \text { phase (n) }\end{array}$ \\
\hline \multirow[t]{2}{*}{$\mathrm{Al}-20 \mathrm{Zn}$} & 01-071-4622 & $\mathrm{Al}$ & 7 & FCC & 400.88 & $3.79 \pm 0.6$ \\
\hline & $01-072-3440$ & $\mathrm{Al}$ & 7 & FCC & & \\
\hline \multirow[t]{3}{*}{$\mathrm{Al}-20 \% \mathrm{Zn}-0.2 \% \mathrm{Sn}$} & 000-052-0856 & $\mathrm{AlZn}$ & 7 & Anorthic & 350.60 & $3.81 \pm 0.2$ \\
\hline & $01-072-3273$ & SnZn & 1 & Hexagonal & & \\
\hline & $01-072-3440$ & $\mathrm{Al}$ & 7 & FCC & & \\
\hline \multirow[t]{3}{*}{ Al-20\%Zn-0.5\%Sn } & 000-052-0856 & AlZn & 7 & Anorthic & 232.50 & $3.89 \pm 0.8$ \\
\hline & $01-072-3273$ & SnZn & 2 & Hexagonal & & \\
\hline & $01-072-3440$ & $\mathrm{Al}$ & 7 & FCC & & \\
\hline \multirow[t]{3}{*}{$\mathrm{Al}-20 \% \mathrm{Zn}-1 \% \mathrm{Sn}$} & $000-052-0856$ & AlZn & 7 & Anorthic & 299.13 & $3.95 \pm 0.6$ \\
\hline & $01-072-3273$ & SnZn & 2 & Tetragonal & & \\
\hline & 01-072-3440 & $\mathrm{Al}$ & 7 & FCC & & \\
\hline \multirow[t]{2}{*}{ Al-20\%Zn-1.5\%Sn } & $000-052-0856$ & AlZn & 7 & Anorthic & 211.70 & $3.94 \pm 0.1$ \\
\hline & $01-072-3273$ & SnZn & 2 & Tetragonal & & \\
\hline
\end{tabular}
be expected to occupy.

Table 2. The details of the XRD analysis of aluminium bearing alloys. 


\subsection{Microstructure}

The microstructures of the resulting melt spun $\mathrm{Al}_{80-\mathrm{x}}-\mathrm{Zn}_{20}-\mathrm{Sn}_{\mathrm{X}}(\mathrm{X}=0,0.2 \%$, $0.5 \%, 1 \%$ and $1.5 \%$ ) alloys of long ribbons of about $65 \mathrm{~mm}$ in thickness and $4 \mathrm{~mm}$ width, are shown in Figure 3 and the mean value and mean deviation of grain size calculated from SEM are listed in Table 3. The smaller value of grain size (5.838 $\mu \mathrm{m})$ is observed in Al-20Zn-1.5Sn melt-spun bearing alloy. The microstructure of $\mathrm{Al}_{80-\mathrm{x}}-\mathrm{Zn}_{20}-\mathrm{Sn}_{\mathrm{X}}(\mathrm{X}=0,0.2 \%, 0.5 \%, 1 \%$ and $1.5 \%)$ bearing alloys are irregular grains with increasing the number of grains with increasing tin content and also $\mathrm{Al}$ phase refined with $\mathrm{Sn}$ addition up to $1.5 \% \mathrm{Sn}$ which leading to improvement of mechanical properties.

(a)

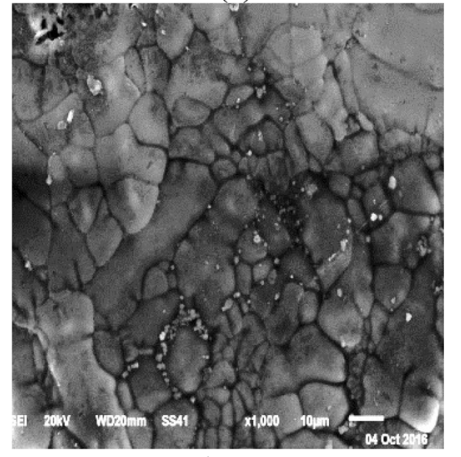

$\mathrm{Al}-20 \mathrm{Zn}$

(d)

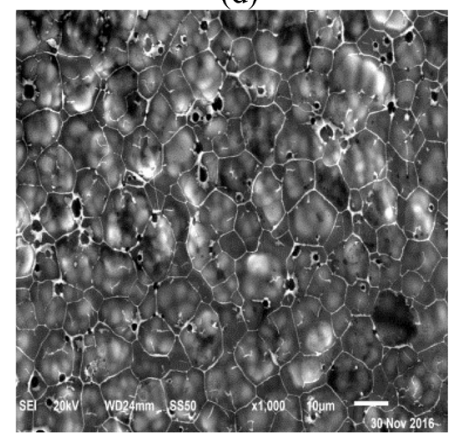

$\mathrm{Al}-20 \mathrm{wt} \% \mathrm{Zn}-1 \mathrm{wt} \% \mathrm{Sn}$ (b)

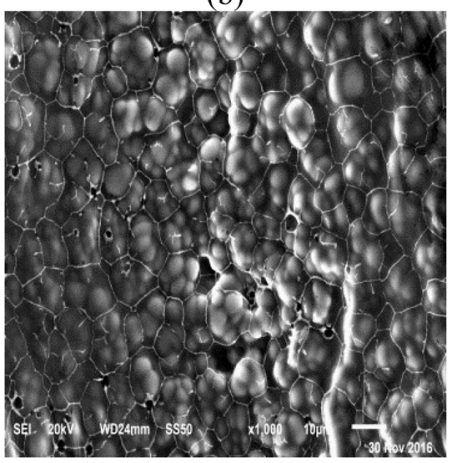

Al-20wt\%Zn-0.2wt\%Sn

(e) (c)

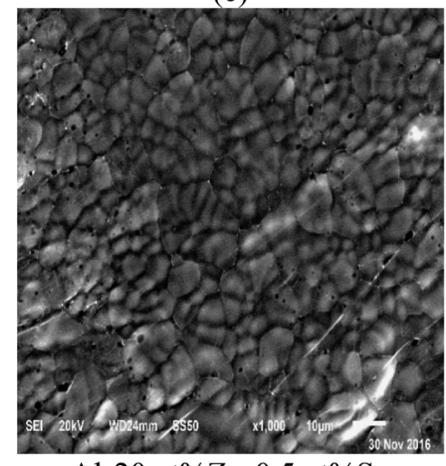

$\mathrm{Al}-20 \mathrm{wt} \% \mathrm{Zn}-0.5 \mathrm{wt} \% \mathrm{Sn}$

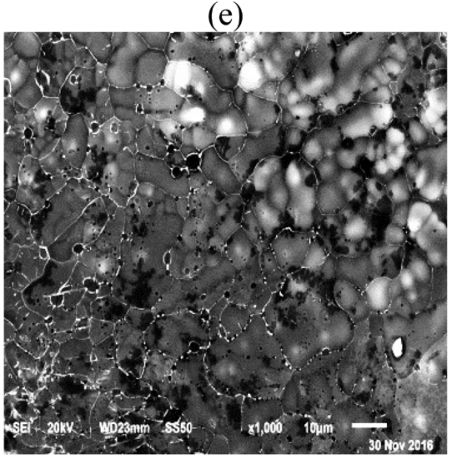

$\mathrm{Al}-20 \mathrm{wt} \% \mathrm{Zn}-1.5 \mathrm{wt} \% \mathrm{Sn}$

Figure 3. SEM micrograph of aluminium bearing alloys.

Table 3. The grain size of SEM micrograph of aluminium bearing alloys from.

\begin{tabular}{cc}
\hline Alloy & Mean Grain size value $(\mu \mathrm{m}) \pm \mathrm{MD}$ \\
\hline Al-20\%Zn & $10.73 \pm 1$ \\
Al-20\%Zn-0.2\%Sn & $12.10 \pm 1.21$ \\
Al-20\%Zn-0.5\%Sn & $6.68 \pm 1.14$ \\
Al-20\%Zn-1\%Sn & $12.05 \pm 0.9$ \\
Al-20\%Zn-1.5\%Sn & $5.84 \pm 0.8$
\end{tabular}

\subsection{Thermal Behavior}

The DSC curves obtained for $\mathrm{Al}_{80-\mathrm{x}}-\mathrm{Zn}_{20}-\mathrm{Sn}_{\mathrm{X}}(\mathrm{X}=0,0.2 \%, 0.5 \%, 1 \%$ and 
1.5\%) melt-spun bearing alloys are shown in Figure 4. A single endothermic peak from the DSC thermo-graphs showed the melting reaction. Melting temperature $T_{m}$, liquidus temperature $T_{L}$, solidus temperature $T_{s}$, enthalpy and entropy change of $\mathrm{Al}_{80-\mathrm{x}}-\mathrm{Zn}_{20}-\mathrm{Sn}_{\mathrm{X}}(\mathrm{X}=0,0.2 \%, 0.5 \%, 1 \%$ and $1.5 \%)$ melt-spun bearing alloys were calculated from DSC graphs and presented in Table 4. By increasing the tin content, the melting point, liquidus and solidus temperatures decreased as indicated from ternary Al-Sn-Zn phase diagram Figure 5 [28]. The melt spinning technique has an effect on the removal of the alloy from equilibrium and therefore the melting temperature will reach $930.7 \mathrm{~K}$ for Al-20Zn$1 \mathrm{Sn}$ and $931.1 \mathrm{~K}$ for Al-20Zn-1.5Sn bearing alloys. This decrease is the result of rapid solidification, compared with other studies [29]. The higher value of enthalpy for Al-20Zn-1.5Sn may be due to decreasing crystal and grain size as indicated from $\mathrm{x}$-ray and microstructure analysis respectively, that leading to enhancement of the mechanical properties. The specific heat $\left(C_{p}\right)$ means the amount of heat per unit mass required to raise the temperature by one degree Celsius, where the specific heat capacity of alloys has been increased by increasing tin content. It is found that entropy change is lower value for $\mathrm{Al}$ 20Zn-1.5 Sn, this result is expected because it has a relatively ordered arrangement of lattice ions.

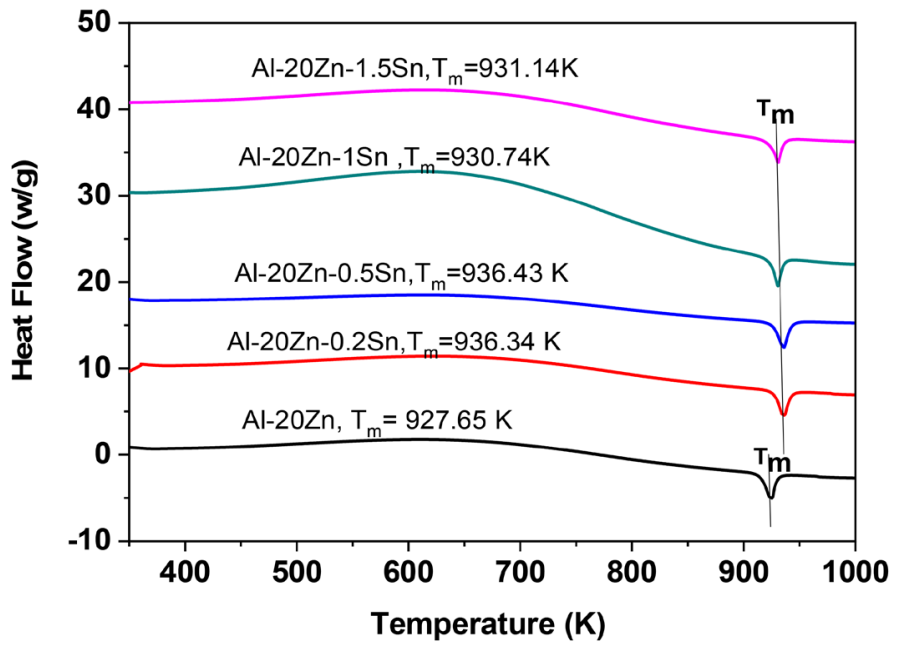

Figure 4. Differential scanning calorimetry (DSC) of aluminium bearing alloys.

Table 4. Thermal analysis of aluminium bearing alloys.

\begin{tabular}{ccccccc}
\hline $\begin{array}{c}\text { Melt-spun } \\
\text { ribbons }\end{array}$ & $\mathrm{T}_{\mathrm{m}}(\mathrm{K})$ & $\mathrm{Ts}(\mathrm{K})$ & $\mathrm{T}_{\mathrm{L}}(\mathrm{K})$ & $\begin{array}{c}\text { Enthalpy } \\
(\mathrm{J} / \mathrm{g})\end{array}$ & $\begin{array}{c}\text { Specific heat } \mathrm{C}_{\mathrm{p}} \\
(\mathrm{J} / \mathrm{g} \cdot \mathrm{k}) \times 10^{-2}\end{array}$ & $\begin{array}{c}\text { Entropy } \\
\text { change }(\mathrm{J} / \mathrm{k})\end{array}$ \\
\hline Al-20Zn & $927.7 \pm 1$ & $922.2 \pm 1$ & $946.2 \pm 1$ & $170.3 \pm 3$ & $4.3 \pm 1$ & $0.220 \pm 0.01$ \\
Al-20Zn-0.2Sn & $936.3 \pm 1.5$ & $927.9 \pm 1.5$ & $953.2 \pm 1.5$ & $183.0 \pm 2$ & $7.2 \pm 1.5$ & $0.194 \pm 0.01$ \\
Al-20Zn-0.5Sn & $936.4 \pm 1$ & $926.2 \pm 1$ & $953.7 \pm 1$ & $178.6 \pm 3$ & $7.9 \pm 2$ & $0.230 \pm 0.01$ \\
Al-20Zn-1Sn & $930.7 \pm 1$ & $923.9 \pm 1$ & $942.1 \pm 1$ & $185.7 \pm 3$ & $8.3 \pm 11$ & $0.199 \pm 0.01$ \\
Al-20Zn-1.5Sn & $931.1 \pm 1$ & $922.6 \pm 1$ & $944.3 \pm 1$ & $189.5 \pm 3$ & $10.2 \pm 2.2$ & $0.192 \pm 0.01$ \\
\hline
\end{tabular}




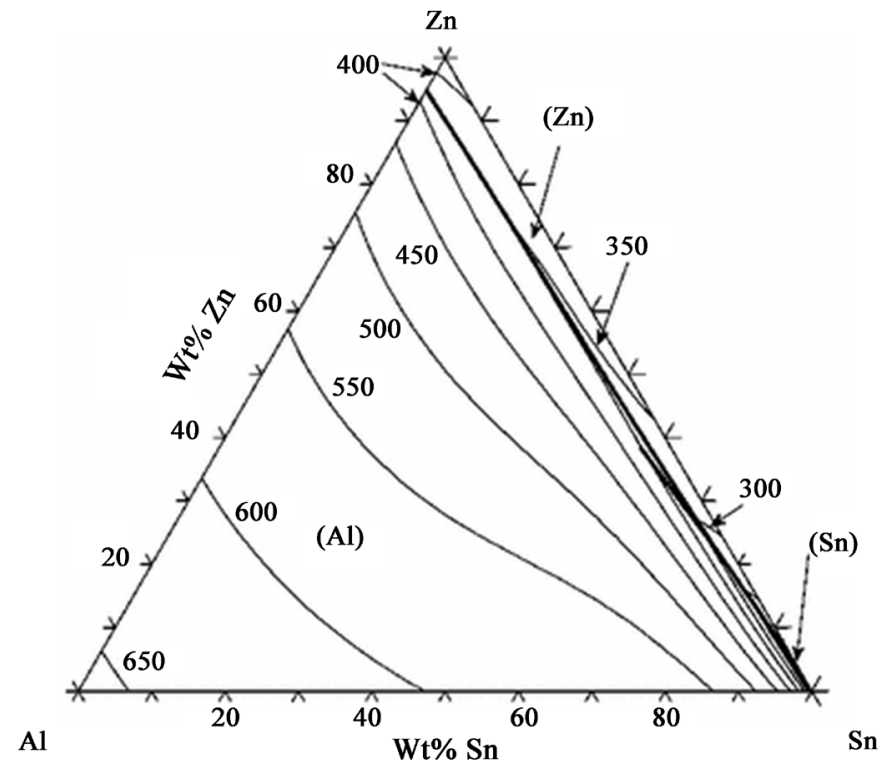

Figure 5. Al-Sn-Zn equilibrium phase diagram [26].

\subsection{Mechanical Behavior}

The stress-strain characteristic curve at room temperature is plotted by using tensile test machine as shown in Figure 6 and elastic moduli (E is the Young's modulus, $G$ is the shear modulus and B is the bulk modulus), tensile strength and yield strength can be calculated then listed in Table 5. The strength of the material is confined by bonding forces, which are reflected by the elastic constants. Tensile strength is the maximum on the stress-strain curve. This corresponds to the maximum stress that can be sustained by a structure in tension [30]. Yield strength is the material property defined as the stress at which a material begins to deform plastically whereas yield point is the point where nonlinear (elastic + plastic) deformation begins. Prior to the yield point, the material will deform elastically and will return to its original shape when the applied stress is removed. Once the yield point is passed, some fraction of the deformation will be permanent and non-reversible [30]. The tensile strength increased in Sn addition from 0 to $1.5 \%$ as in good agreement with that of typical $\mathrm{Al}$ alloys [31]. Adding content of Sn depends on the Sn softening and the cracking of the porosity produced which effect hardness and tensile properties of the alloys [32]. From

Table 5. Elastic moduli and tensile properties of aluminium bearing alloys.

\begin{tabular}{cccccccc}
\hline $\begin{array}{c}\text { Melt-spun } \\
\text { ribbons }\end{array}$ & $\begin{array}{c}\text { Tensile } \\
\text { strength } \\
(\mathrm{MPa})\end{array}$ & $\begin{array}{c}\text { Yield } \\
\text { strength } \\
(\mathrm{MPa})\end{array}$ & $\begin{array}{c}\text { Toughness } \\
\left(\mathrm{J} / \mathrm{m}^{3}\right) \times 10^{6}\end{array}$ & $\begin{array}{c}\mathrm{CSS} \\
(\mathrm{GPa})\end{array}$ & $\begin{array}{c}\mathrm{E} \\
(\mathrm{GPa})\end{array}$ & $\mathrm{G}(\mathrm{GPa})$ & $\mathrm{B}(\mathrm{GPa})$ \\
\hline $\mathrm{Al}-20 \mathrm{Zn}$ & $351.9 \pm 22$ & $323.2 \pm 8$ & $3.6 \pm 1.1$ & $10.6 \pm 1$ & $72.8 \pm 7$ & $26.9 \pm 7$ & $82.1 \pm 7$ \\
$\mathrm{Al}-20 \mathrm{Zn}-0.2 \mathrm{Sn}$ & $174.0 \pm 12$ & $168.3 \pm 5$ & $3.6 \pm 0.9$ & $5.9 \pm 1$ & $23.6 \pm 10$ & $8.7 \pm 10$ & $26.6 \pm 10$ \\
$\mathrm{Al}-20 \mathrm{Zn}-0.5 \mathrm{Sn}$ & $449.3 \pm 9$ & $356.4 \pm 14$ & $13.3 \pm 2$ & $7.6 \pm 1$ & $79.6 \pm 6$ & $29.4 \pm 6$ & $89.7 \pm 6$ \\
$\mathrm{Al}-20 \mathrm{Zn}-1 \mathrm{Sn}$ & $261.1 \pm 4$ & $254.2 \pm 17$ & $5.9 \pm 1$ & $5.8 \pm 1$ & $71.9 \pm 5$ & $26.6 \pm 5$ & $81.1 \pm 5$ \\
$\mathrm{Al}-20 \mathrm{Zn}-1.5 \mathrm{Sn}$ & $680.2 \pm 15$ & $573.6 \pm 9$ & $23.1 \pm 2.1$ & $10.0 \pm 1$ & $125.1 \pm 11$ & $46.3 \pm 11$ & $140.9 \pm 11$ \\
\hline
\end{tabular}




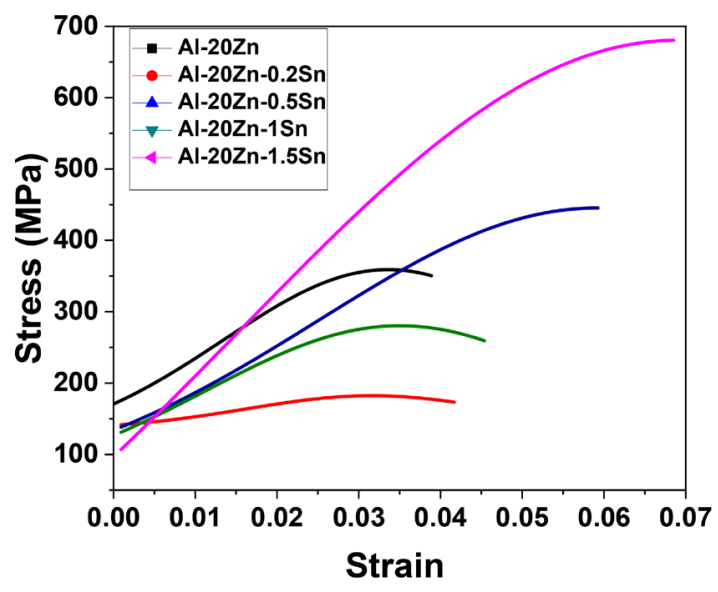

Figure 6. Stress-strain characteristic curves of aluminium bearing alloys.

microstructure analysis, it is indicated that incresing $\mathrm{Sn}$ content leading to increase the number of grains and also $\mathrm{Al}$ phase refined with $\mathrm{Sn}$ addition. So that tensile strength, yield strength and elastic moduli increased. The Al-20Zn-1.5Sn melt-spun bearing alloy shows a maximum increase of the Young's modulus value of $125 \pm 11 \mathrm{GPa}$, the tensile strength of $680 \pm 15 \mathrm{MPa}$ and yield strength of $573 \pm 9 \mathrm{MPa}$. In the Al-20Zn-0.5Sn and Al-20Zn-1.5Sn alloys graphs, the stress profiles do not decrease after the maximum stress value like the rest of the alloys. Because, these alloys are high ductile and strength compared with other alloys. In order to be tough, a material must be both hard and ductile as indicated from stress-strain diagram of Al-20Zn-1.5 Sn alloy. When the shear stress reaches the value of the critical resolved shear stress, the plastic deformation begins as indicated in Figure 5. The critical shear stress CSS shows the maximum value of 10 $\pm 1 \mathrm{GPa}$ for Al-20Zn-1.5Sn melt-spun bearing alloy. The ability of a material to absorb energy then deform plastically without fracturing is the toughness of the material [33]. By integrating the stress-strain curve in Figure 5, toughness can be calculated and listed in Table 5. It shows maximum toughness value of ( $23 \pm$ 2.1) $\times 10^{6} \mathrm{~J} / \mathrm{m}^{3}$ for Al-20Zn-1.5Sn bearing alloy.

\subsection{Hardness Indentation and Micro-Creep Dependence of Tin Composition}

The indentation length versus tin composition of the melt spun $\mathrm{Al}_{80-\mathrm{x}}-\mathrm{Zn}_{20}-\mathrm{Sn}_{\mathrm{X}}$ $(\mathrm{X}=0,0.2 \%, 0.5 \%, 1 \%$ and $1.5 \%)$ bearing alloys at constant load $10 \mathrm{gf}$ and indentation time 5 seconds are shown in Figure 7, where the indentation length shows the smallest value at $1.5 \mathrm{wt} \% \mathrm{Sn}$. The variation of Vickers hardness with tin composition at constant load $10 \mathrm{gf}$ and indentation time 5 seconds is showed in Figure 8. The average hardness values of $\mathrm{Al}_{80-\mathrm{x}}-\mathrm{Zn}_{20}-\mathrm{Sn}_{\mathrm{X}}(\mathrm{X}=0,0.2 \%, 0.5 \%, 1 \%$ and $1.5 \%$ ) bearing alloys are listed in Table 6. It is noted that average hardness values increase by increasing Sn content up to $1.5 \%$ Sn from $240 \pm 11$ to $275 \pm$ $11 \mathrm{MPa}$. The stress exponent calculated from Equation (5) and listed in Table 6 according to [34] and [35]: 


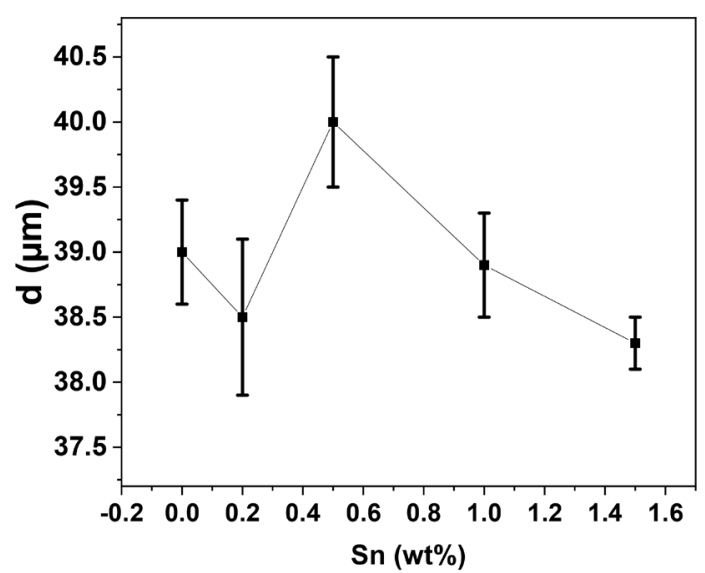

Figure 7. Variation of indentation length with tin composition at indentation time $5 \mathrm{sec}$ and constant load 10 gf for aluminium bearing alloys.

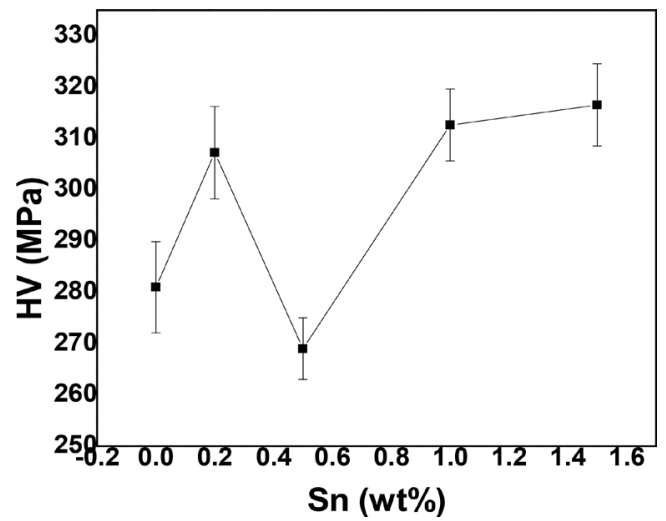

Figure 8. Variation of hardness versus tin composition at indentation time $5 \mathrm{sec}$ and constant load $10 \mathrm{gf}$ for aluminium bearing alloys.

Table 6. Hardness and Stress exponent value of aluminium bearing alloy.

\begin{tabular}{ccc}
\hline Melt-spun ribbons & HV $(\mathrm{MPa})$ & $\mathbf{n}$ \\
\hline Al-20Zn & $202.6 \pm 18$ & 1.2 \\
Al-20Zn-0.2Sn & $240.8 \pm 12$ & 2.4 \\
Al-20Zn-0.5Sn & $238.8 \pm 15$ & 3.1 \\
Al-20Zn-1Sn & $244.3 \pm 16$ & 3.5 \\
Al-20Zn-1.5Sn & $275.1 \pm 11$ & 4.2 \\
\hline
\end{tabular}

$$
n=\left[\frac{\partial \ln \dot{d}}{\partial \ln H_{v}}\right]_{d}
$$

The stress exponent that is calculated from Equation (5) is used to determine deformation mechanisms, where $H_{V}$ is the number of Vickers hardness, $d$ is the length of indentation diagonal, and $\dot{d}$ is variation rate of diagonal indentation length. The stress exponent $\mathrm{n}$ is calculated from the slope of straight line obtained by plotting $\dot{d}$ against $H_{V}$ on double logarithmic scale as indicated in Figure 9 [36]. The stress exponent is indication of mechanism of deformation during room 

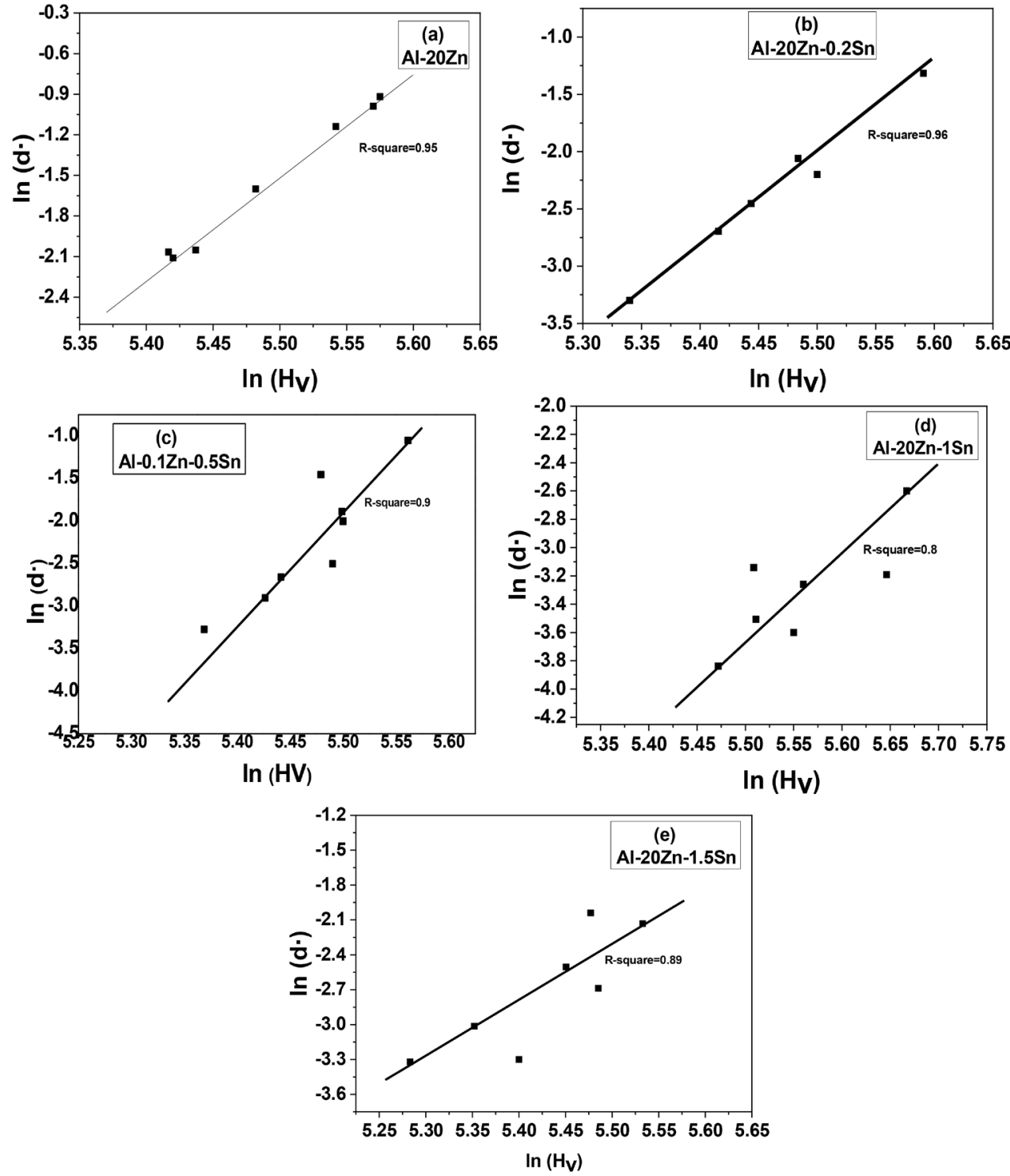

Figure 9. $\ln$-ln of the Vickers hardness numbers against the dwell time of indentation at load 10 gf for aluminum bearing alloys.

temperature. The stress exponent (n) values in the range $2.4-4.2$ as shown in Table 6, indicate that the grain boundary sliding is the possible mechanism during room temperature creep deformation of melt spun $\mathrm{Al}_{80-\mathrm{x}}-\mathrm{Zn}_{20}-\mathrm{Sn}_{\mathrm{X}}(\mathrm{X}=0,0.2 \%$, $0.5 \%, 1 \%$ and $1.5 \%$ ) bearing alloys in good agreement with that of typical $\mathrm{Al}$ alloys [37].

The indentation creep behavior is shown in Figure 10 by plotting strain against indentation time (indentation creep curve) of $\mathrm{Al}_{80-\mathrm{x}}-\mathrm{Zn}_{20}-\mathrm{Sn}_{\mathrm{X}}(\mathrm{X}=0,0.2 \%, 0.5 \%$, $1 \%$ and $1.5 \%$ ) bearing alloys. The first stage shows faster increase of strain with indentation time which starts from beginning up to $10 \mathrm{sec}$ of indentation time. Second stage indicates a slow increase region for all alloys where the strain increased slowly. Fracture of the specimen does not occur because hardness test is 


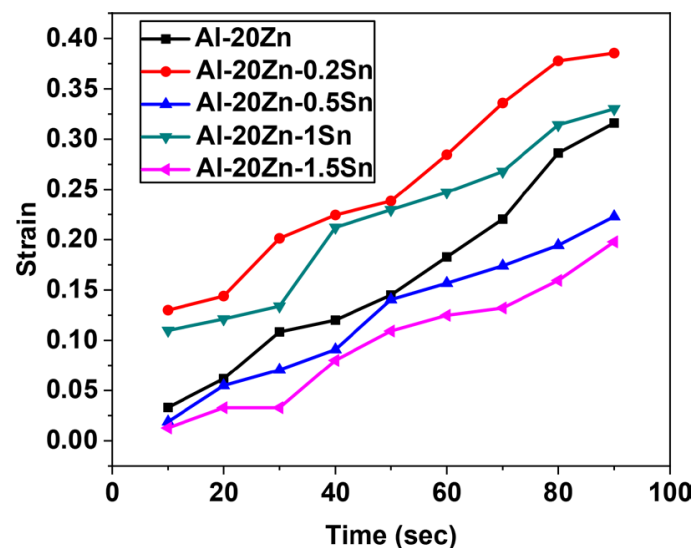

Figure 10. The Creep behaviour of aluminium bearing alloys.

actually a compression test therefore the third stage cannot be recorded as happened in an ordinary creep test. According to the power law creep, the creep rate decreased when the stress exponent for Al-20Zn-1.5Sn bearing alloy increased due to an increase in yield strength [38]. Therefore, the higher value of stress exponent $(\mathrm{n})$ and yield strength of Al-20Zn-1.5Sn bearing alloy is more resistant to creep of indentation compared to $\mathrm{Al}_{80-\mathrm{x}}-\mathrm{Zn}_{20}-\mathrm{Sn}_{\mathrm{X}}(\mathrm{X}=0,0.2 \%, 0.5 \%, 1 \%$ and $1.5 \%)$ bearing alloys.

\section{Conclusions}

- In the present work, the influence of RSP and tin addition on structure, thermal and mechanical properties of melt spun Al-Zn-Sn bearing alloys were investigated.

- The Al-20Zn-1.5Sn has a smaller crystallite size and grain size as indicated from $\mathrm{X}$-ray and SEM analysis respectively, which leads to the enhancement of the mechanical properties.

- The Al-20Zn-1.5Sn melt-spun bearing alloy shows a maximum increase of the Young's modulus value of $125 \pm 11 \mathrm{GPa}$, the tensile strength of $680 \pm 15 \mathrm{MPa}$, yield strength of $573 \pm 9 \mathrm{MPa}$, toughness value of $(23 \pm 2.1) \times 10^{6} \mathrm{~J} / \mathrm{m}^{3}$ and critical shear stress CSS of $10 \pm 1 \mathrm{GPa}$.

- The stress exponent $(\mathrm{n})$ values in the range $2.4-4.2$ indicate that the grain boundary sliding is the possible mechanism during room temperature creep deformation of melt spun Al-Zn-Sn bearing alloys.

- The higher value of stress exponent (n) and yield strength of Al-20Zn-1.5Sn bearing alloy is more resistant to creep of indentation.

\section{Conflicts of Interest}

The authors declare no conflicts of interest regarding the publication of this paper.

\section{References}

[1] Mathavan, J.J. and Patnaik, A. (2016) Analysis of Wear Properties of Aluminium 
Based Journal Bearing Alloys with and without Lubrication. IOP Conference Series: Materials Science and Engineering, 149, Article ID: 012052. https://doi.org/10.1088/1757-899X/149/1/012052

[2] Schouwenaars, R., Torres, J.A., Jacobo, V.H. and Ortiz, A. (2007) Tailoring the Mechanical Properties of Al-Sn Alloys for Tribological Application. Materials Science Forum, 539-543, 317-322. https://doi.org/10.4028/www.scientific.net/MSF.539-543.317

[3] Apelian, D. (2009) Aluminum Cast Alloys, Enabling Tools for Improved Performance. North American Die Casting Association, Wheel Illinois.

[4] Lamrous, D., Debili, M.Y. and Courjault, E.B. (2013) Microstructure and Phase Composition of Al-Zn Alloys. Journal of Advanced Microscopy Research, 8, 266-269. https://doi.org/10.1166/jamr.2013.1168

[5] Yan, L., Zhang, Y., Li, X., Li, Z., Wang, F., Liu, H. and Xiong, B. (2014) Effect of Zn Addition on Microstructure and Mechanical Properties of an Al-Mg-Si Alloy. Progress in Natural Science: Materials International, 24, 97-100. https://doi.org/10.1016/j.pnsc.2014.03.003

[6] Sun, Z.B., Guo, J., Song, X.P., Zhu, Y. and Li, Y. (2008) Effects of Zr Addition on the Liquid Phase Separation and the Microstructures of Cu-Cr Ribbons with 18-22 at. \%. Journal of Alloys and Compounds, 455, 243-248. https://doi.org/10.1016/j.jallcom.2007.01.152

[7] Huang, L.J., Liang, G.Y., Sun, Z.B. and Zhou, Y.F. (2007) Nano Crystallization and Hydriding Properties of Amorphous Melt-Spun $\mathrm{Mg}_{65} \mathrm{Cu}_{25} \mathrm{Nd}_{10}$ Alloy. Journal of Alloys and Compounds, 432, 172-176. https://doi.org/10.1016/j.jallcom.2006.06.026

[8] Yang, S., Song, X.P. and Liu, X.S. (2003) Magnetic Properties Enhancement of $\mathrm{Nd}_{2}$ $\mathrm{Fe}_{14} \mathrm{~B} / \alpha$-Fe Nano Composites with a Combined Addition of $\mathrm{Cu}$ and Ti. Journal of Applied Physics, 93, 1199-1202. https://doi.org/10.1063/1.1530368

[9] Totik, Y. and Gavgali, M. (2002) The Effect of Homogenization Treatment on the Hot Workability between the Surface and the Center of AA 2014 Ingots. Materials Characterization, 49, 261-268. https://doi.org/10.1016/S1044-5803(03)00030-5

[10] Saka, H., Nishikawa, Y. and Imura, T. (1988) Melting Temperature of In Particles Embedded in an Al Matrix. Philosophical Magazine A, 57, 895-906. https://doi.org/10.1080/01418618808204524

[11] Zhang, D.L. and Cantor, B. (1991) Melting Behavior of In and Pb Particles Embedded in an Al Matrix. Acta Metallurgica et Materialia, 39, 1595-1602. https://doi.org/10.1016/0956-7151(91)90247-X

[12] Kim, W.T. and Cantor, B. (1991) Solidification of Tin Droplets Embedded in an Aluminum Matrix. Journal of Materials Science, 26, 2868-2878. https://doi.org/10.1007/BF01124815

[13] Zhang, D.L., Hutchinson, J.L. and Cantor, B. (1994) Melting Behavior of Cadium Particles Embedded in an Aluminum Matrix. Journal of Materials Science, 29, 2147-2151. https://doi.org/10.1007/BF01154693

[14] Osório, W.R., Cheung, N., Spinelli, J.E., Goulart, P.R. and Garcia, A. (2007) The Effects of a Eutectic Modifier on Microstructure and Surface Corrosion Behavior of AlSi Hypoeutectic Alloys. Journal of Solid State Electrochemistry, 11, 1421-1427. https://doi.org/10.1007/s10008-007-0300-x

[15] Osório, W.R., Peixoto, L.C., Moutinho, D.J., Gomes, L.G., Ferreira, I.L. and Garcia, A. (2011) Corrosion Resistance of Directionally Solidified Al-6Cu-1Si and Al-8Cu3Si Alloys Castings. Materials \& Design, 32, 3832-3837. https://doi.org/10.1016/j.matdes.2011.03.013 
[16] Osório, W.R., Garcia, L.R., Goulart, P.R. and Garcia, A. (2007) Effects of Eutectic Modification and T4 Heat Treatment on Mechanical Properties and Corrosion Resistance of an Al-9 wt\%Si Casting Alloy. Materials Chemistry and Physics, 106, 343-349. https://doi.org/10.1016/j.matchemphys.2007.06.011

[17] Donelan, P. (2000) Modelling Microstructural and Mechanical Properties of Ferritic Ductile Cast Iron. Materials Science and Technology, 16, 261-269. https://doi.org/10.1179/026708300101507811

[18] Petch, N.J. (1953) The Cleavage Strength of Polycrystals. The Journal of the Iron and Steel Institute, 174, 25-31.

[19] Kamal, M., Shaban, A.M., El-Kady, M. and Shalaby, R.M. (1996) Irradiation, Mechanical, and Structural Behavior of Al-Zn-Based Alloys Rapidly Quenched from Melt. Radiation Effects and Defects in Solids, 138, 307-318.

https://doi.org/10.1080/10420159608211533

[20] Suryanarayana, C. and Anantharaman, T.R. (1970) Solidification of Aluminum-Germanium Alloys at High Cooling Rates. Journal of Materials Science, 5, 992-1004. https://doi.org/10.1007/BF00558182

[21] Hehmann, F., Sommer, F. and Predel, B. (1990) Extension of Solid Solubility in Magnesium by Rapid Solidification. Materials Science and Engineering. A, 125, 249-265. https://doi.org/10.1016/0921-5093(90)90175-3

[22] Geller, Y.A. and Rakhshtadt, A.G. (1977) Science of Materials. SciMAT, 138, 138141.

[23] Fawzy, A., Fayek, S.A., Sobhy, M., Nassr, E., Mousa, M.M. andSaad, G. (2013) Effect of $\mathrm{ZnO}$ Nanoparticles Addition on Thermal, Microstructure and Tensile Properties of Sn-3.5 Ag-0.5 Cu (SAC335) Solder Alloy. Journal of Materials Science: Materials in Electronics, 24, 3210-3218. https://doi.org/10.1007/s10854-013-1230-2

[24] Cao, Z.H., Li, P.Y. and Meng, X.K. (2009) Nanoindentation Creep Behaviors of Amorphous, Tetragonal, and Bcc Ta Films. Materials Science and Engineering: A, 516, 253 258. https://doi.org/10.1016/j.msea.2009.03.019

[25] Shibutani, T., Yu, Q. and Shiratori, M. (2007) A Study of Deformation Mechanism during Nanoindentation Creep in tin-Based Solder Balls. Journal of Electronic Packaging, 129, 71-75. https://doi.org/10.1115/1.2429712

[26] Edward, S., Orson, L.A. and Naohiro, S. (1973) Elastic Constants and Their Measurements. Mc Graw-Hill Book Company, New York, 82.

[27] Cullity, B.D. and Weymouth, J.W. (1957) Elements of X-Ray Diffraction. American Journal of Physics, 25, 394-395. https://doi.org/10.1119/1.1934486

[28] Smetana, B., Zlá, S., Kroupa, A., Žaludová, M., Drápala, J., Burkovič, R. and Petlák, D. (2012) Phase Transition Temperatures of Sn-Zn-Al System and Their Comparison with Calculated Phase Diagrams. Journal of Thermal Analysis and Calorimetry, 110, 369-378. https://doi.org/10.1007/s10973-012-2318-2

[29] Kamal, M. and Gouda, E.S. (2006) Effect of Rapid Solidification on Structure and Properties of Some Lead-Free Solder Alloy. Materials and Manufacturing Processes, 21, 736740. https://doi.org/10.1080/10426910600727890

[30] Callister, W.D. and Rethwisch, D.G. (2013) Materials Science and Engineering. An Introduction, 9th Edition, Wiley, Hoboken.

[31] Si, Y. (2018) Research on Hardness and Tensile Properties of A390 Alloy with Tin Addition. IOP Conference Series: Materials Science and Engineering, 322, Article No. 022038. https://doi.org/10.1088/1757-899X/322/2/022038

[32] Haque, M.M. and Sharif, A. (2001) Study on Wear Properties of Aluminum-Silicon 
Piston Alloy. Journal of Materials Processing Technology, 118, 69-73. https://doi.org/10.1016/S0924-0136(01)00869-X

[33] Brian, L. (2001-2011) Fracture Toughness, NDT Resource Center, Iowa State University, Ames.

[34] Juhász, A., Tasnádi, P. and Kovács, I. (1986) Superplastic Indentation Creep of LeadTin Eutectic. Journal of Materials Science Letters, 5, 35-36. https://doi.org/10.1007/BF01671427

[35] Mahmudi, R., Geranmayeh, A.R., Mahmoodi, S.R. and Khalatbari, A. (2007) RoomTemperature Indentation Creep of Lead-Free Sn-Bi Solder Alloys. Physica Status Solidi $(A)$, 204, 2302-2308. https://doi.org/10.1002/pssa.200622583

[36] Roumina, R., Raeisinia, B. and Mahmudi, R. (2004) Room Temperature Indentation Creep of Cast Pb-Sb Alloys. Scripta Materialia, 51, 497-502. https://doi.org/10.1016/j.scriptamat.2004.05.048

[37] Xu, Y., Yang, L., Zhan, L., Yu, H. and Huang, M. (2019) Creep Mechanisms of an Al$\mathrm{Cu}-\mathrm{Mg}$ Alloy at the Macro- and Micro-Scale: Effect of the S'/S Precipitate. Mat, Materials, 12, Article ID: 2907. https://doi.org/10.3390/ma12182907

[38] Cseh, G., Bär, J., Gudladt, H.J., Lendvai, J. and Juhász, A. (1999) Indentation Creep in a Short Fibre Reinforced Metal Matrix Composite. Materials Science and Engineering: $A$, 272, 145-151. https://doi.org/10.1016/S0921-5093(99)00466-9 